\title{
Bone of the Lower Extremity
}

National Cancer Institute

\section{Source}

National Cancer Institute. Bone of the Lower Extremity. NCI Thesaurus. Code C12982.

A bone of the leg (lower extremity). 